\title{
Peranan General Affair di Sebuah Hotel "Studi Kasus : General Affair di Hotel The Westlake Resort Yogyakarta"
}

\author{
${ }^{1}$ Dhimas Setyo Nugroho, ${ }^{2}$ Nurnita Indriyani \\ ${ }^{1}$ Universitas BSI, dhimas42@gmail.com \\ ${ }^{1}$ Universitas BSI, nurnitaindriyani1994@gmail.com
}

\begin{abstract}
ABSTRAK
Artikel ini membahas tugas General Affair di hotel The Westlake Resort Yogyakarta Hotel. Data dikumpulkan melalui wawancara, pengamatan dan dokumentasi. Artikel ini membahas lebih luas tentang tugas-tugas General Affair di hotel, masalah yang dihadapi, terutama dalam menghadapi kurangnya ruang penyimpanan seragam dan kurangnya stok seragam. Solusi dalam menghadapi masalah-masalah ini adalah menyimpan seragam di dalam gudang departemen Housekeeping dan bagi semua karyawan yang menggunakan seragam untuk mengisi formulir aset properti.
\end{abstract}

Kata Kunci: Hotel, General Affair, Seragam

ABSTRACT

This article explores a task of a general affair in The Westlake Resort Yogyakarta Hotel. Data were collected through interviews, observation and documentation. This article discusses more broadly about the duties of general affair at the hotel, the problems encountered, especially in addressing the lack of a uniform storage space and lack of stock uniform. The solution in the face of these problems is to keep the uniform in the warehouse Department housekeeping and require all employees who use the uniform to fill the property asset form.

Keywords: Hotel, General Affair, Uniform.

Diterima: 21 September 2018, Direvisi: 10 Oktober 2018, Diterbitkan: 15 Februari 2019

\section{PENDAHULUAN}

Hampir disemua perusahaan memiliki sebuah bagian yang disebut general affair (GA) yang mendukung kegiatan operasional perusahaan dan mengurus segala urusan rumah tangga perusahaan. Tugas general affair cukup kompleks karena harus saling berinteraksi dan berkoordinasi di lingkungan internal perusahaan, maupun secara eksternal dengan pihak di luar perusahaan. Umumnya general affair (GA) membawahi bagian maintenance and housekeeping, building management and infrastructure, sistem keamanan, general purchasing, inventory asset, customer service, facility service, healthy and safety serta perizinan dan humas. Meski pada umumnya general affair membawahi beberapa bagian tersebut, tidak semua general affair di masing-masing perusahaan memiliki tugas dan tanggung jawab yang sama. General affair di sebuah perusahaan yang menghasilkan produk berupa barang, dengan perusahaan yang menghasilkan produk berupa barang dan jasa tentu memiliki tugas dan tanggung jawab yang berbeda.
Beberapa tugas general affair di perusahaan percetakan PT. Suraconforin, Surabaya adalah membantu dalam penagihan pembayaran kepada pembeli, membantu menjaga kerapihan dan kebersihan di dalam perusahaan, membantu kasir melakukan penyetoran uang ke bank dan membantu menurunkan barang ketika ada barang datang dari supplier. Sedangkan tugas general affair di perusahaan manufaktur PT. Intera Lestari Polimer, Banten meliputi mengelola perbaikan gedung dan fasilitas pendukung, mengontrol peralatan perusahaan dan perbaikan kerusakan gedung, membuat jadwal perawatan gedung. Selanjutnya tugas general affair di perusahaan PT CJ Foodville Bakery and Cafe Indonesia (TOUS les JOURS) yang bergerak di bidang bakery and cafe adalah mengontrol dan membuat laporan tagihan listrik, telepon, tagihan internet di gudang dan kantor, melaksanakan kegiatan pengadaan barang untuk memastikan ketersediaan barang dalam jumlah yang tepat waktu. Bertanggung jawab terhadap persiapan transportasi, penginapan dan akomodasi seluruh perjalanan dinas 
karyawan. Masing-masing perusahaan memiliki kebutuhan berbeda, tergantung dari lingkup struktur besarnya perusahaan dan kebutuhan operasional perusahaan. Oleh karena itu, tugas dan tanggung jawab general affair pada setiap perusahaan tidaklah sama. Berbeda lagi jika perusahaan tersebut berupa hotel, tugas general affair di sebuah hotel tentu berbeda pula dengan tugas general affair di perusahaan lain. Selain itu, minimnya penelitian yang membahas tugas general affair di hotel juga belum ada. Berdasarkan latar belakang diatas, penulis tertarik untuk meneliti tugas, masalah dan solusi yang dilakukan seorang general affair di sebuah hotel, dengan studi kasus di hotel The Westlake Resort Yogyakarta.

\section{KAJIAN LITERATUR}

General Affair diartikan bagian umum yang merupakan salah satu bagian departemen di dalam sebuah perusahaan yang menjadi pendukung atas aktivitas operasional perusahaan. General Affair membawahi bagian keamanan (security), kebersihan (cleaning service), pengemudi (driver), kurir (messenger), administrasi umum, office boy, receptionist, pengadaan barang (purchasing), pengelolaan parkir (parking operation), K3 (kesehatan dan keselamatan kerja) atau healthy safety environtment (HSE) (Hambudi, 2015). Sedangkan menurut Guswandy (2017) mengemukakan bahwa General Affair adalah sebuah posisi yang berada dibawah pimpinan Divisi Umum atau Kepala Operasional, biasa disebut dengan GA".

\section{METODE PENELITIAN}

Peneliti menggunakan pendekatan studi kasus untuk menyelidiki kejadian atau masalah yang telah terjadi mengenai operasional general affair dan tugas-tugas general affair di hotel The Westlake Resort Yogyakarta (Creswell dalam Sugiyono, 2011). Peneliti hanya sebagai pengamat independen, sehingga tidak terlibat langsung dengan aktivitas di hotel The Westlake Resort Yogyakarta (Sutrisno Hadi dalam Sugiyono, 2011). Peneliti mengamati dan mencatat gejalagejala yang diselidiki tentang general affair dan tugas-tugas general affair (Hadari, 2005). Peneliti menggunakan teknik wawancara dengan pedoman wawancara berupa berupa garis-garis besar permasalahan yang ingin ditanyakan (Sugiyono, 2011). Peneliti mewawancarai informan kunci kepada Human Resources Manager dan Human Resources Admin. Hal ini dilakukan karena karena posisi general affair di hotel The Westlake Resort Yogyakarta berada dalam wewenang Human
Resources Department. Selain itu peneliti mengambil data berupa foto dan dokumen dari hotel The Westlake Resort Yogyakarta yang diperlukan untuk menyelesaikan penelitian (Mahadewi dan Rai, 2012). Penelitian ini fokus pada tugas general affair di hotel The Westlake Resort Yogyakarta.

\section{HASIL DAN PEMBAHASAN \\ Deskripsi Operasional Human Resources Department Hotel The Westlake Resort Yogyakarta}

Di hotel The Westlake Resort Yogyakarta, seorang Human Resources Manager bertugas memperbaiki manajemen yang ada di The Westlake Resort Yogyakarta mulai dari menerapkan kembali Standar Operasional Prosedur Perusahaan (SOP) dan Job Description (Job Desk), memperbarui atau memperpanjang kontrak karyawan di bantu oleh Human Resources Supervisor yang pada umumnya bertugas memberikan pelatihan terhadap para karyawan baru. Human Resources Admin bertugas mengurus administrasi seperti absensi karyawan dan di bantu oleh seorang General Affair yang bertugas untuk mendata property asset perusahaan salah satunya adalah mendata seragam karyawan (uniform).

\section{Tugas General Affair di Hotel The Westlake Resort Yogyakarta}

Seorang general affair di hotel The Westlake Resort Yogyakarta bertanggung jawab terhadap pemenuhan perijinan yang diperlakukan perusahaan.. Menjaga terpeliharanya hubungan baik dengan lingkungan sekitar perusahaan.. Menyiapkan laporan secara periodik keberadaan dan kondisi asset perusahaan salah satunya uniform. Pengontrolan fasilitas kantor. Pengontrolan keamanan seluruh fasilitas kantor dan asset perusahaan. Mendata property asset salah satunya adalah uniform. Uniform di hotel The Westlake Resort Yogyakarta sendiri terdiri dari; Polo T-Shirt yang digunakan oleh semua departemen pada hari senin hingga kamis kecuali bagian Back Office dan House Keeping. Batik Hijau yang digunakan digunakan semua departemen pada hari jumat dan sabtu. Seragam House Keeping yang digunakan departemen House Keeping pada hari senin hingga kamis. Seragam Engineering yang digunakan departemen Engineering setiap hari. Semua uniform di Hotel The Westlake Resort Yogyakarta tersebut disimpan didalam kantor Human Resources Department. 


\section{Masalah yang dihadapi General Affair di Hotel The Westlake Resort Yogyakarta}

Semua uniform di Hotel The Westlake Resort Yogyakarta disimpan di dalam kantor Human Resources Department. Hal ini mengakibatkan kondisi kantor menjadi terasa sesak. Uniform menjadi tertumpuk dan tidak tertata rapi. Selain itu seringnya karyawan yang baru bergabung justru secara mendadak mengundurkan diri dari perusahaan, padahal kontrak kerjanya baru saja dibuat. Hal tersebut menimbulkan masalah lain, yaitu uniform yang tidak dikembalikan oleh karyawan tersebut, sehingga stock uniform di hotel The Westlake Resort Yogyakarta semakin berkurang.

\section{Solusi General Affair Di Hotel The Westlake Resort Yogyakarta.}

Sementara waktu uniform disimpan di gudang Housekeeping agar tertata rapi dan tidak menumpuk di ruang Human Resources Department. Namun hal ini justru menimbulkan masalah baru. Uniform menjadi sering hilang karena tidak adanya konfirmasi dari karyawan Housekeeping ke Human Resources Department ketika mereka mengambil uniform. Akibatnya stock uniform menjadi semakin berkurang. Dampak terburuk dari masalah tersebut adalah karyawan yang baru bergabung di perusahaan tersebut tidak mendapatkan uniform, sehingga mereka tidak dapat bekerja. Uniform merupakan pakaian kerja yang memiliki fungsi, nilai dan makna penting bagi seluruh karyawan diperusahaan. Uniform juga berfungsi sebagai identitas atau tanda pengenal yang mampu memberiakan kesan pertama dimata customer atau relasi. Uniform juga dapat memberikan citra positif bagi suatu perusahaan dan mampu menjadi media promosi. Solusi general affair dalam mengatasi kurangnya stock uniform adalah mendata kembali uniform dengan cara meminta setiap karyawan mengisi property asset form. Property asset form adalah formulir yang di isi oleh setiap karyawan yang akan meminjam uniform. Dengan begitu seorang General Affair akan lebih mudah dalam mengecek stock uniform yang ada.

Property asset form berisi nama peminjam, posisi di perusahaan, departemen dan tanggal peminjaman. Selain itu juga berisi apa saja uniform yang di pinjam serta jumlah uniform yang di pinjam dan tanda tangan peminjam. Fungsi dari form tersebut yaitu mempermudah seorang General Affair dalam mendata property asset yang dimiliki perusahaan sehingga tidak akan terjadi permasalahan seperti data uniform yang tidak sesuai dengan stock uniform di perusahaan. Terutama karyawan di bagian Back Office untuk uniform Polo-Tshirt ditarik kembali untuk mengantisipasi kurangnya uniform karena banyaknya karyawan baru dan anak $O n$ The Job Training di The Westlake Resort Yogyakarta.

\section{KESIMPULAN DAN REKOMENDASI}

General Affair di Hotel The Westlake Resort Yogyakarta memiliki beberapa tugas penting dalam menjaga dan memelihara hubungan ke luar perusahaan dan di dalam perusahaan.. Selain itu general affair juga harus membuat laporan secara periodik keberadaan dan kondisi asset perusahaan salah satunya uniform. Dalam operasionalnya general affair di hotel The Westlake Resort Yogyakarta mengalami kendala dalam mengelola uniform karyawan. Masalah tersebut berupa tidak adanya ruang penyimpanan uniform dan kurangnya stock uniform. Untuk menghadapi masalah tersebut, general affair menitipkan uniform di gudang Housekeeping dan mewajibkan karyawan yang meminjam seragam untuk mengisi property asset form. Hal ini untuk mengontrol uniform yang beredar dan mendata stock uniform yang ada di hotel The Westlake Resort Yogyakarta.

\section{DAFTAR PUSTAKA}

Hadari, Nawawi. (2005). Penelitian Terapan. Yogyakarta: Gajah Mada University Press.

Hambudi, Teguh. (2015). \#1 Profesional : General Affair. Jakarta Selatan : Visimedia. Mahadewi, E. Ni Made dan Rai Utama, I.G. Bagus. (2012). Metode Penelitian Pariwisata dan Perhotelan. Yogyakarta. Penerbit: CV Andi Offset.

Sugiyono. (2011). Metode Penelitian Kuantitatif Kualitatif dan $R \& D$. Cetakan ke 14. Bandung : Alfabeta.

Guswandy, Rant. 2017. Tugas dan Fungsi General Affair. Diambil dari : https://www.linovhr.com/tugas-dan-fungsigeneral-affair/ diakses pada 24/08/2018 pukul 16.00

https://www.loker.id/human-resources/generalaffair/lowongan-kerja-general-affair-ptsuraconforin-surabaya.html (diakses 24/08/2018 pukul 04.20) PT. Suraconforin, Surabaya

https://id.indeed.com/viewjob?jk=50414557a048 c3c3\&q $=$ General+Affair + Staff $\&$ tk $=1 \mathrm{clka} 8$ $6 u 00$ sou67o \& from $=$ web $\& v j s=3$ (diakses 
24/08/2018 pukul 04.41) PT. Intera Lestari Polimer

https://www.jobstreet.co.id/id/job/general-affairstaff-2580574? fr $=23 \& \mathrm{src}=12$ (diakses pada 24/08/2018 pukulo 04.56) PT CJ Foodville Bakery and Cafe Indonesia ( TOUS les JOURS )

\section{BIODATA}

${ }^{1}$ Dhimas Setyo Nugroho : Dhimas Setyo Nugroho S.Par., M.M. adalah dosen jurusan perhotelan di Univeristas BSI Yogyakarta. Pendidikan S1 diselesaikan di STP AMPTA Yogyakarta. Pendidikan S2 diselesaikan di Universitas Sarjanawiyata Tamansiswa Yogyakarta.

${ }^{2}$ Nurnita Indriyani : Nurnita INdriyani adalah salah mahasiswa jurusan perhotelan di Universitas BSI Yogyakarta. 